\title{
A Comparative Study of Influence of Ascorbic Acid and Other Organic Acid on Corrosion of Mild Steel Using Mössbauer Spectroscopy
}

\author{
Kashyap Dhoot ${ }^{1}$ \\ ${ }^{\text {I}(D e p a r t m e n t ~ o f ~ P h y s i c s, ~ J a i ~ N a r a y a n ~ V y a s ~ U n i v e r s i t y, ~ I n d i a) ~}$
}

\begin{abstract}
In present investigation a systematic study of role of Ascorbic Acid and other organic acids like Salicylic Acid, Acetyl Salicylic Acid and Maleic Acid, of different strength, on corrosion of Mild Steel in corrosive media brackish water is carried out. It is observed that the Ascorbic Acid of concentration 0.05M and higher in corrosive media brackish water effectively influences the formation of usual corrosion species and also retards the rate of rust formation while for other organic acid it is observed that these acids are not able to suppress the formation of usual corrosion product
\end{abstract}

Keywords: Ascorbic Acid, Corrosion of Mild Steel, Mössbauer Spectroscopy, Organic Acids

\section{INTRODUCTION}

Chemical transformation of the surface of the metal and alloys are of immense techno economic importance. The efficacy of some of the reducing agents in inhibition of corrosion of mild steel is reported by

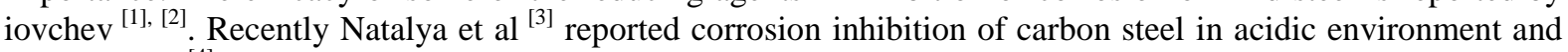
Adriana et $\mathrm{al}^{[4]}$ have reported corrosion inhibition of carbon steel in hydrochloric acid solution.

In the present work a systematic study of influence of ascorbic acid and some organic acid on corrosion of mild steel in brackish water has been carried out. The aim of the study is to see the influence of these acids in the formation of corrosion product. Mössbauer spectroscopy is used because it is suitable for the identification of chemical state of iron.

\section{EXPERIMENTAL}

All the chemicals used were of analytical reagent grade. Mild steel plates of size $2.5 * 2.5 * 2.5 \mathrm{~cm}^{3}$ were first polished mechanically and degreased by the acetone and benzene prior to use.

These plates were emerged in the solution of ascorbic acid of strength $0.02 \mathrm{M}$ and higher and Salicylic Acid, Acetyl Salicylic Acid and Maleic Acid of strength 0.1M for different exposure time of 10-60 days. The loss of water due to evaporation was compensated by addition of deionized water twice a day. After desired time of exposure samples were dried at room temperature and then the rust was scrapped from the surface by a fine glass knife for Mössbauer Spectroscopic investigation. Experimental setup and Instrumental details are described in Nigam et al ${ }^{[5]}$.

\section{RESULT AND DISCUSSION}

Typical Mössbauer Spectra of rust due to brackish water, ascorbic acid are shown in figure 1 and 2 respectively. Mössbauer parameters obtained for these spectrums are given in table 1 and 2. Typical Mössbauer Spectra due to other organic acids are shown in figure 3 and Mössbauer parameters for these spectrums are given in table 3.

From table 2 it is clear that ascorbic acid of concentration $>0.05 \mathrm{M}$ effectively suppress the formation of usual corrosion product and it also retards the rate of rust formation. While from table 3 it is clear that other organic acids are not able to suppress the formation of usual corrosion products however Ferrihydrite to $\beta . \gamma$ $\mathrm{FeOOH}$ ratio is increased corresponding to the control solution.

The possible reason to account for why ascorbic acid inhibits corrosion while other organic acids failed to do so may be due to the difference in their functional group. Ascorbic acid has active phenolic group and it is well know that phenols inhibits the corrosion.

Table 1. Mössbauer parameters for the rust of mild steel due to exposure in
Brackish water.
\begin{tabular}{cllllll}
\hline $\begin{array}{c}\text { Exposure } \\
\text { Time (days) }\end{array}$ & Doublet & $\begin{array}{c}\text { QS } \\
(\mathrm{mm} / \mathrm{s})\end{array}$ & $\begin{array}{c}\text { IS } \\
(\mathrm{mm} / \mathrm{s})\end{array}$ & LW & $\begin{array}{l}\mathrm{A} \\
(\%)\end{array}$ & Species \\
\hline 15 & $\mathrm{AA}^{\prime}$ & 0.66 & 0.30 & 0.50 & 64.0 & $\mathrm{Fe}^{3+}$ \\
15 & $\mathrm{BB}^{\prime}$ & 0.71 & 0.49 & 0.38 & 27.0 & $\mathrm{Fe}^{3+}$ \\
15 & $\mathrm{CC}^{\prime}$ & 2.34 & 0.96 & 0.38 & 9.0 & $\mathrm{Fe}^{2+}$ \\
60 & $\mathrm{AA}^{\prime}$ & 0.66 & 0.31 & 0.52 & 67.0 & $\mathrm{Fe}^{3+}$ \\
60 & $\mathrm{BB}^{\prime}$ & 0.71 & 0.41 & 0.39 & 20.0 & $\mathrm{Fe}^{3+}$ \\
60 & $\mathrm{CC}^{\prime}$ & 2.41 & 0.96 & 0.36 & 13.0 & $\mathrm{Fe}^{2+}$ \\
\hline
\end{tabular}


A Comparative Study Of Influence Of Ascorbic Acid And Other Organic Acid On Corrosion Of Mild

Table 2. Mössbauer parameters for the rust of mild steel due to exposure in brackish water containing ascorbic acid.

\begin{tabular}{|c|c|c|c|c|c|c|c|}
\hline $\begin{array}{l}\text { Exposure } \\
\text { Time }\end{array}$ & $\begin{array}{l}\text { Concentration of } \\
\text { ascorbic } \operatorname{acid}(\mathrm{M})\end{array}$ & Doublet & $\begin{array}{c}\mathrm{QS} \\
(\mathrm{mm} / \mathrm{s})\end{array}$ & $\begin{array}{c}\mathrm{IS} \\
(\mathrm{mm} / \mathrm{s})\end{array}$ & LW & $\begin{array}{l}\mathrm{A} \\
(\%)\end{array}$ & Species \\
\hline 15 & 0.02 & $\mathrm{AA}^{\prime}$ & 0.87 & 0.38 & 0.49 & 69.0 & Ferrihydrite \\
\hline 15 & 0.02 & $\mathrm{BB}^{\prime}$ & 0.50 & 0.37 & 0.35 & 25.0 & $\beta, \gamma-\mathrm{FeOOH}$ \\
\hline 15 & 0.02 & $\mathrm{CC}^{\prime}$ & 2.27 & 0.90 & 0.34 & 6.0 & $\mathrm{FeCl}_{2} \cdot 4 \mathrm{H}_{2} \mathrm{O}$ \\
\hline 15 & 0.05 & $\mathrm{AA}^{\prime}$ & 0.90 & 0.34 & 0.36 & 12.0 & Ferrihydrite \\
\hline 15 & 0.05 & DD' & 1.71 & 1.21 & 0.30 & 88.0 & $?$ \\
\hline 60 & 0.02 & $\mathrm{AA}^{\prime}$ & 1.03 & 0.38 & 0.37 & 18.0 & Ferrihydrite \\
\hline 60 & 0.02 & $\mathrm{BB}^{\prime}$ & 0.62 & 0.37 & 0.51 & 71.0 & $\beta, \gamma-\mathrm{FeOOH}$ \\
\hline 60 & 0.02 & $\mathrm{CC}^{\prime}$ & 2.26 & 0.91 & 0.36 & 11.0 & $\mathrm{FeCl}_{2} \cdot 4 \mathrm{H}_{2} \mathrm{O}$ \\
\hline 60 & 0.05 & $\mathrm{BB}^{\prime}$ & 0.60 & 0.33 & 0.52 & 67.0 & $\beta, \gamma-\mathrm{FeOOH}$ \\
\hline 60 & 0.05 & DD' & 1.74 & 1.16 & 0.33 & 33.0 & $?$ \\
\hline 60 & 0.1 & $\mathrm{BB}^{\prime}$ & 0.58 & 0.18 & 0.30 & 10.0 & $\beta, \gamma-\mathrm{FeOOH}$ \\
\hline 60 & 0.1 & DD' & 1.73 & 1.21 & 0.35 & 90.0 & $?$ \\
\hline 60 & 0.5 & DD' & 1.72 & 1.21 & 0.34 & 100.0 & $?$ \\
\hline
\end{tabular}

Table 3. Mössbauer parameters for the rust of mild steel due to exposure in brackish water containing organic acid of concentration $0.1 \mathrm{M}$.

\begin{tabular}{|c|c|c|c|c|c|c|c|}
\hline $\begin{array}{l}\text { Exposure } \\
\text { Time(days) }\end{array}$ & $\begin{array}{l}\text { Name of organic } \\
\text { acid }\end{array}$ & Doublet & $\begin{array}{c}\mathrm{QS} \\
(\mathrm{mm} / \mathrm{s})\end{array}$ & $\begin{array}{c}\mathrm{IS} \\
(\mathrm{mm} / \mathrm{s})\end{array}$ & LW & $\begin{array}{l}\text { A } \\
(\%)\end{array}$ & Species \\
\hline \multirow[t]{2}{*}{20} & Salicylic & $\mathrm{AA}^{\prime}$ & 0.57 & 0.35 & 0.39 & 49.0 & $\beta, \gamma-\mathrm{FeOOH}$ \\
\hline & & BB' & 0.99 & 0.35 & 0.44 & 51.0 & Ferrihydrite \\
\hline \multirow[t]{2}{*}{30} & Salicylic & $\mathrm{AA}^{\prime}$ & 0.63 & 0.35 & 0.40 & 68.0 & $\beta, \gamma-\mathrm{FeOOH}$ \\
\hline & & BB' & 1.04 & 0.36 & 0.41 & 32.0 & Ferrihydrite \\
\hline \multirow[t]{2}{*}{20} & Acetyl Salicylic & $\mathrm{AA}^{\prime}$ & 0.58 & 0.35 & 0.38 & 65.0 & $\beta, \gamma-\mathrm{FeOOH}$ \\
\hline & & BB' & 1.02 & 0.34 & 0.39 & 35.0 & Ferrihydrite \\
\hline \multirow[t]{2}{*}{30} & Acetyl Salicylic & $\mathrm{AA}^{\prime}$ & 0.54 & 0.35 & 0.36 & 45.0 & $\beta, \gamma-\mathrm{FeOOH}$ \\
\hline & & BB' & 0.94 & 0.34 & 0.50 & 55.0 & Ferrihydrite \\
\hline \multirow[t]{2}{*}{10} & Maleic & $\mathrm{AA}^{\prime}$ & 0.56 & 0.35 & 0.38 & 48.0 & $\beta, \gamma-\mathrm{FeOOH}$ \\
\hline & & BB' & 0.99 & 0.35 & 0.45 & 52.0 & Ferrihydrite \\
\hline \multirow[t]{2}{*}{20} & Maleic & AA' $^{\prime}$ & 0.62 & 0.34 & 0.42 & 72.0 & $\beta, \gamma-\mathrm{FeOOH}$ \\
\hline & & BB' & 1.08 & 0.35 & 0.35 & 28.0 & Ferrihydrite \\
\hline \multirow[t]{2}{*}{30} & Maleic & $\mathrm{AA}^{\prime}$ & 0.64 & 0.36 & 0.42 & 83.0 & $\beta, \gamma-\mathrm{FeOOH}$ \\
\hline & & BB' & 1.15 & 0.37 & 0.30 & 17.0 & Ferrihydrite \\
\hline
\end{tabular}

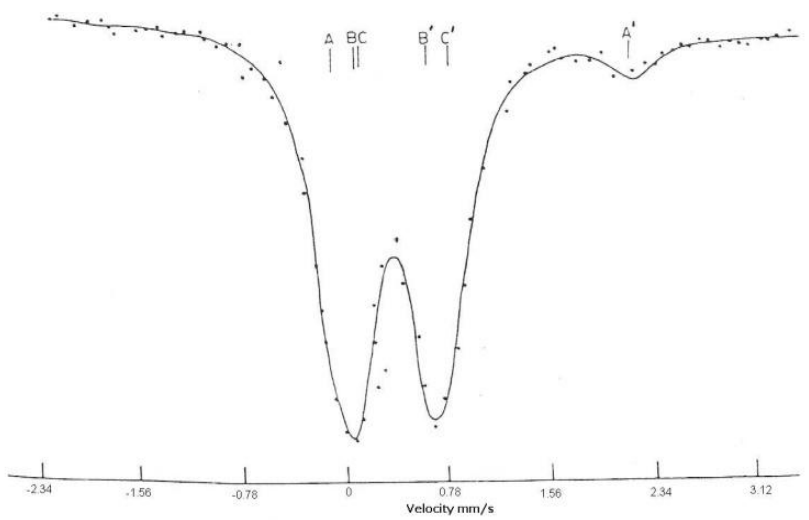

Fig. 1. Mössbauer spectra of rust due to Brackish Water (15Days). 

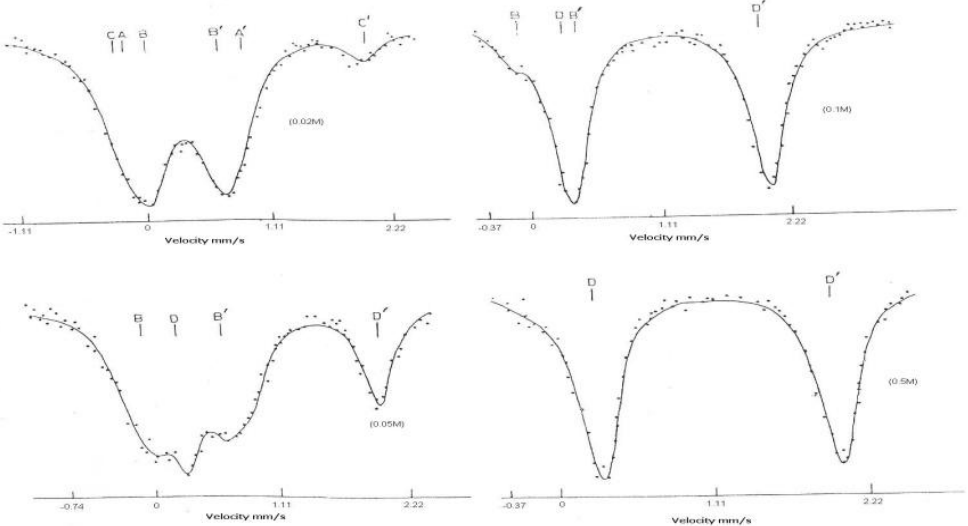

Fig 2. Mössbauer Spectra of rust due to Brackish Water containing Ascorbic Acid (60 Days)

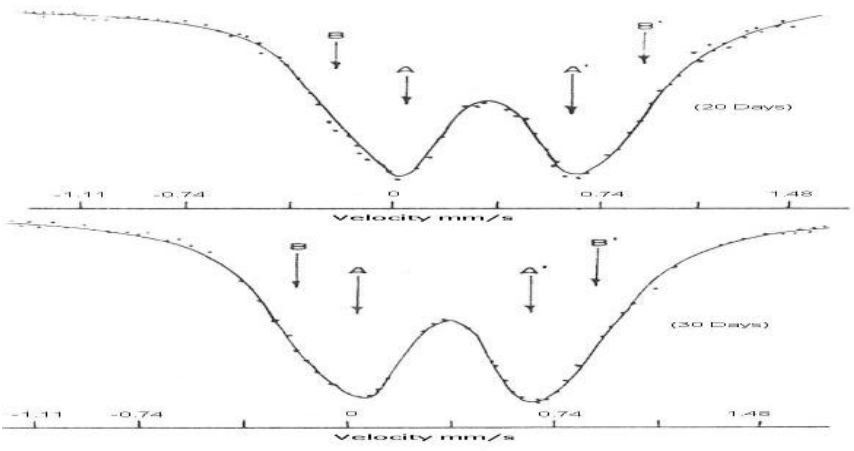

Fig. 3(a). Acetyl Salicylic Acid of Strength 0.1M

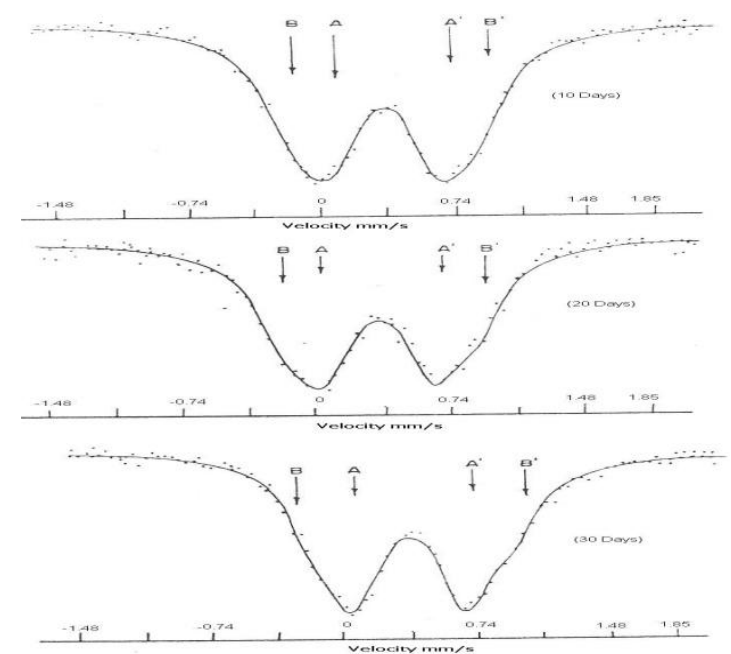

Figure 3(b). Maleic Acid of Strength 0.1M

Fig. 3 Mössbauer Spectra of rust due to Organic Acids

References

[1] M. Iovchev, Br. Corsos. Journal vol. 18 no. 3 148(1983).

[2] M. Iovchev, Desalination, 52,285(1985).

[3] Natalya V. Likhanova, Octavio Olivares-Xomet, Diego Guzmán-Lucero Int. J. Electrochem. Sci., 6 (2011) 4514 - 4536.

[4] Adriana Patru, Samide Ion, Mircea Predaa Materials Letters Volume 62, Issue 2, 31 January 2008, Pages 320-322.

[5] A.N. Nigam, R.P. Tripathi, M.L. Jangid and M.P. Chacharkar J. RADIOANAL. Nucl. Chem. letters, 117, 4, 243(1987). 